\section{Fee Hunting in Western South Dakota ${ }^{1}$}

\section{F. ROBERT GARTNER AND KIETH E. SEVERSON}

Associate Professor of Animal Science (Range Ecology), South Dakota State University, Agricultural Research \& Extension Center; and Range Scientist, Rocky Mountain Forest and Range Experiment Station, 2 Forest Service, U. S. Department of Agriculture, Rapid City, South Dakota.

\section{Highlight}

A new fee hunting system in western South Dakota is described. Its development, operation and probable reasons for future success or failure are suggested. Economic influences alone may encourage development of similar hunting systems, especially as increased hunting pressure is felt by landowners. This paper presents an approach which could further the cause of range management while simultaneously maximizing the economic return from rangeland.

Orville Freeman, former Secretary of Agriculture, stated a decade ago that "while we can expect substantial expansion of public recreation areas in the years ahead, it is apparent that they cannot by themselves meet the booming national demand. Unfortunately, most publicly owned forests, parks, shorelands, and associated water areas are far removed from centers of population. Consequently, it is inevitable that a very high proportion of future outdoor recreation in this country will take place on or in association with privately owned facilities" (Freeman, 1952).

\footnotetext{
${ }^{1}$ Approved by the director of the South Dakota Agricultural Experiment Station as Journal Series No. 1036. The authors express their appreciation to officers and members of Dakota Safaris, Inc. for their cooperation in making this publication possible. Received December 3, 1971.

${ }^{2}$ Station's central headquarters maintained in cooperation with Colorado State University at Fort Collins. Research reported here was conducted in cooperation with the South Dakota School of Mines and Technology at Rapid City.
}

Historically, free access for the purpose of hunting, fishing, camping, and other forms of outdoor recreation has been taken for granted by most South Dakota residents. State laws hold that wild game belongs to the people, although most of the forage consumed and the land inhabited by game animals is in private ownership.

Despite the feelings of hunters, farmers in the vicinity of the Missouri River have been charging a fee for goose hunting since the late 1930's. In more recent years, some eastern South Dakota farmers have charged for pheasant hunting or have leased hunting rights to individuals or clubs. These migratory waterfowl and resident upland game birds make relatively light use of either native or introduced forages or cultivated crops compared to resident big game such as deer. Yet, in the open spaces of the western South Dakota range country, nearly all ranches have been open to the public for hunting of both big and small game.

\section{Development of Fee Hunting in Western South Dakota}

Unique under these circumstances is a group of five ranch owners who united in 1966 to sell a hunting experience. Located in the heart of excellent deer, antelope, grouse, and potentially good turkey habitat, they initially joined together to prohibit all public hunting on their lands. That action was the result of several years of ever increasing numbers of hunters. Added to the increased hunting pressure was the labor involved in closing gates, repairing fences and "patrolling" to control vehicular travel over damage-vulnerable areas of the ranch. "Nuisance factors"-giving permission and directions at odd hours, removing mired vehicles, pouring gas for those with empty tanks, and packing deer out of inaccessible areasaggravated the situation. Livestock lost to the careless or wanton shooter, while not frequent, contributed to the hunting ban. 
Restricted hunting resulted in a rapid increase in deer numbers. Competition with livestock for forage intensified, and damage to hay meadows, stacks, and cultivated crops increased. A system of profitable deer harvest became not only a desirable objective, but was deemed necessary.

The outcome of these circumstances was Dakota Safaris, a corporation formed in 1969. The original five ranchers were joined by three additional landowners in the fall of 1970. The salable "by-product" of these eight range livestock operations is hunting trophy mule deer. A trophy buck, in this case, is one with four points or more on one side. Initially the corporation advertised hunting "prairie" deer, Black Hills deer, and "trophy" bucks. It was soon obvious that the greatest demand was for trophy buck hunting.

\section{Location and Description of the Hunting Area}

The hunting area, about 45 air miles northeast of Rapid City and the Black Hills, encompasses about 100 square miles. Natural geographic boundaries exist on the north (the Belle Fourche River) and on the east (the Cheyenne River). Interstate 90 borders the area on the south. Only a small percentage of the Dakota Safaris hunting area lies outside those boundaries.

Elk Creek, which flows from the Black Hills eastward to the Cheyenne River, and many lesser drainages have created scenic rough breaks and highly productive overflow sites. The combination of native or improved haylands, water, and cover affords excellent habitat for both mule and white-tailed deer.

The predominantly clayey soils of the area were derived from the Pierre shale formation, and range from very shallow to moderate in depth, depending on topographic position. Vegetation is typically Mixed Prairie on the uplands, dominated by western wheatgrass (Agropyron smithii) and green needlegrass (Stipa viridula) with an understory of blue grama (Bouteloua gracilis) and buffalograss (Buchloe dactyloides) when the range is properly managed. Clayey soils are also typified by a wide variety of forbs.

Shallow soils on steeper slopes support a complex of both warm- and cool-season grasses. In high condition these sites support big and little bluestem (Andropogon gerardi and $A$. scoparius), sideoats grama (Bouteloua curtipendula), prairie sandreed (Calamovilfa longifolia), western wheatgrass, and green needlegrass. Also occurring under proper management are many shrubs and forbs, including leadplant amorpha (Amorpha canescens), skunkbush sumac (Rhus trilobata), silver buffaloberry (Shepherdia argentea), chokecherry (Prunus virginiana), western snowberry (Symphoricarpos occidentalis), bigtop dalea (Dalea enneandra), black sampson (Echinacea angustifolia), several species of scurfpea (Psoralea spp.) and vetches (Vicea spp.), and many others.
Table 1. Disposition of the 1970 hunting fee on a daily basis, Dakota Safaris, Inc.

\begin{tabular}{lr}
\hline \multicolumn{1}{c}{ Disposition } & Amount \\
\hline Landowner (for each hunter) & $\$ 20.00$ \\
Guide Service (to rancher) & 11.00 \\
Meals & 9.00 \\
Lodging & 5.00 \\
Insurance & 2.00 \\
Management (Dakota Safaris, Inc.) & 5.00 \\
Overhead (Dakota Safaris, Inc.) & 10.50 \\
Total & $\$ 62.50^{1}$
\end{tabular}

${ }^{1}$ Four day package @ $\$ 250.00$.

Along the river and creek bottoms, deciduous trees such as plains cottonwood (Populus sargentil), willow (Salix spp.), and green ash (Fraxinus pennsylvanica) grow profusely. Poorly developed soils on rather steep slopes above these drainages support Rocky Mountain juniper (Juniperus scopulorum) in open to rather dense stands. A few scattered stands of ponderosa pine (Pinus ponderosa) also exist in the breaks above the Cheyenne River.

\section{Physical Facilities, Hunting Fees, and Services Provided}

A hunter has the option of staying either in a central hunting camp or at one of the ranches. Most prefer the camp, which is located in the center of the controlled area on Elk Creek. Heated rooms, hot and cold running water, and beds are provided in each of several buildings. Hunters must provide their own sleeping bags. Meals are prepared by a Rapid City catering service with a mobile unit that merely backs into the ground-level garage of the main house. The rest of the garage serves as a dining room and place for hunters and ranchers to socialize.

Hunter charges were initially $\$ 35.00$ per day in the fall of 1966. Daily fees were ultimately eliminated because of problems with reservations and excess food which accumulated as a result of the expert or lucky hunter who shot his trophy the first day then departed. A 3- or 4-day "package" hunt was substituted for the daily fee. As unexpected costs developed the fee was gradually increased, yet hunter numbers increased from 8 in 1966 to 56 in 1970.

Logically, there are some hidden costs to the landowner who wishes to initiate a trophy deer hunt. Deferment of hunting for one or more years may be necessary to build up the trophy buck numbers. As with most new businesses, the initial costs of advertising and promotion may be high. Likewise, the charges for management and overhead may be expensive the first few years, but may, in fact, decrease thereafter.

The $\$ 250.00$ fee in 1970 for a 4-day hunt was broken down as indicated in Table 1. Future charges are projected at $\$ 300.00$ with references required. 
Theoretically, then, in the brief 9-day "prairie deer" season permitted by present South Dakota game laws, only two trophy hunts can be planned. The income to the rancher depends upon whether or not he guides, feeds, and provides lodging for the hunter. His return can be from $\$ 20$ to $\$ 45$ per hunter-day depending upon services he provides. Theoretically, a member rancher may realize as much as $\$ 3,600$ if he has 10 hunters for 8 days. Landowner costs are, likewise, a function of services rendered.

\section{Discussion}

Of what advantage is controlled hunting to the landowner? There are several direct and indirect benefits:

1. The landowner has complete control of recreational users.

2. Livestock losses during the deer season have been eliminated on lands under the control of Dakota Safaris, Inc. Hunters are told they can shoot all the cattle they desire. They will be charged only $50 \phi$ per pound (liveweight) for cattle shot, and the animals will be hauled to the nearest locker plant, processed, and the shooter billed accordingly. No cattle have been shot in five years of trophy hunting.

3. Many new social contacts have been made by Dakota Safaris' rancher members. Very few ranchers have the opportunity to meet and discuss hunting, recreation, politics, business, and other matters with visitors from other geographic areas, some of whom are corporate executives. Most of the guests can be classified as middle-income, bluecollar workers or hourly wage earners. These are avid sportsmen willing to pay for a quality deer hunt.

4. The rancher becomes a part of the economically fruitful recreation business. He is paid for supplying an all-terrain vehicle, horses, guiding, and for land use. While many resident sportsmen who have enjoyed free hunting feel that any hunting fee it too great, many non-resident hunters are willing to pay for the privilege to hunt and for services provided. Assuming the local (Rapid City) scale for most services (electrician, mechanic, plumber, etc.) to be approximately $\$ 8.00$ per hour, the potential return to the landowner of $\$ 31.00$ per day does not appear excessive.

Both landowners and local businesses benefit from the economic input of the recreationist dollar. Diverse income is also good insurance against drought and poor markets. Under a controlled hunting system such as the Dakota Safaris operation, the landowner can rightly say at the close of a hunting season that he enjoyed the season. In the past the same landowner considered the deer hunting season an annual problem that occupied much of his time and could result in direct monetary loss.

5. This awareness could promote better range management. Corporation members now recognize that proper range management pays a dividend not only in better quality and quantity of forage and greater calf weaning weights, but also in more and healthier deer. This new awareness over a wide area may prove to be the key incentive for landowners to better manage the total rangeland environment. Such awareness and subsequent improved management is contingent, however, upon the understanding and cooperation of both sportsmen and the Department of Game, Fish and Parks. Landowners must also be willing to devclop the overall range resource-a task that may require some changes in management philosophy.

Game that was formerly considered a liability is now considered a potential asset and source of income by members of Dakota Safaris. That attitude could prevail throughout much of western South Dakota. Antelope, for example, were considered a nuisance by many ranchers in the area, because of their damage to alfalfa and wheat fields. Now they are viewed as another potential source of income compatible with the ranch operation and numbers are increasing. Thus, rangeland productivity could become more diverse, healthier, and provide greater recreation opportunity for more pcoplc.

At this point we should repeat the comments of Jack Knetsch (1966): "For private provision of outdoor recreation to be profitable and feasible there must be a market and a marketable product. Sellers must be in a position to withhold the product or service so that buycrs arc forced to pay a price to make use of the facilities."

Several groups of ranchers, controlling larger blocks of land than presently under the Dakota Safaris system, have inquired of that corporation about procedures to organize a similar operation. It is highly probable that many large acreages of deeded land in western South Dakota will eventually be under some type of fee hunting system. If direct or indirect controls by state agencies prohibit or restrict such enterprises, game populations may be purposely reduced by landowners who are no longer willing to bear the burden of supporting either native herbivores or hunters without some monetary return.

Many private landowners find it difficult to withhold recreation use of their areas from the public. The private developer is often under considerable economic pressure to manage resources in ways that would lower its quality at least in part (Knetsch, 1966).

The landowners involved in the Dakota Safaris venture are faced with difficult social, legal, and biological barriers in their attempt to optimize production from their lands. Not the least of these is the deer population imbalance caused by annual harvest of 
predominantly trophy bucks while not removing surplus females. Time will undoubtedly reduce some of these problems, provided the landowner fulfills his responsibilities to the total range resource. Acceptance of fee hunting systems by sportsmen and state agencies is essential to insure the success of such ventures. Cooperation between landowners and the South Dakota Department of Game, Fish, and Parks is also imperative, especially in the matter of big game damage claims by landowners and the number of licenses available to both residents and non-residents.

\section{Literature Cited}

Freeman, Orville L. 1962. Rural Recreation. U. S. Dep. Agr., Washington, D. C. (See also Foreword in: Report of Workshop on Income-Producing Recreation Enterprises at Denver, Colo. Soil Conserv. Serv., Washington, D. C. April 30, 1963).

KNETSCH, JACK L. 1966. Financing public outdoor recreation. Nat. Conf. on Policy Issues in Outdoor Recreation, Sept. 6-8, 1966, Logan, Utah. (Paper distributed by Bureau of Outdoor Recreation, U. S. Dep. of the Interior, Washington, D. C.). 